Available Online at https://journal.unismuh.ac.id/index.php/otoritas

Otoritas : Jurnal Ilmu Pemerintahan, 9 (1), April 2019, 42-55

\title{
The role of ICT in Addressing Corruption Across Political Regimes
}

\author{
Mergen Dyussenov ${ }^{1,2 *}$ \\ ${ }^{1}$ Institute of Management, the Academy of Public Administration under the President of Kazakhstan, \\ 33a Abay avenue, Astana, 01000, Kazakhstan. \\ ${ }^{2}$ Lee Kuan Yew School of Public Policy, National University of Singapore, \\ 469 Bukit Timah road, 259772, Singapore.
}

Received: 6 September 2018; Revised: 27 February 2019; Accepted: 13 March 2019

\begin{abstract}
The paper reviews existing literature on the role of the internet in addressing corruption by breaking it down into instrumental, important, and critical roles, across two types of political regimes - (semi) authoritarian and democracies. It analyzes the key resources and strategies utilized by governments and activists across these regimes, and looks into the common themes that emerge as a result of analyzing literature sources, i.e. the notion of crisis, lack of a single accepted definition of corruption across nations, factors found to positively correlate with reduced corruption, and the evolving nature of the internet. The paper finds that neither regime can be perfectly immune against mass-scale protests caused by dissatisfaction with worsening corruption. However, the regimes differ in the nature of protests, with semi-authoritarian regimes witnessing more violent and aggressive uprisings fueled by long-accumulated social disappointment with previous repressive regimes than across much of democracies.
\end{abstract}

Keywords: ICT; Corruption; Political Regime; Developing Nations

How to Cite: Dyussenov, M. (2019). The Role of ICT in Adressing Corruption Across Political Regimes. Otoritas : Jurnal Ilmu Pemerintahan, 9(1), 42-55.

Permalink/DOI: https://doi.org/10.26618/ojip.v9i1.1508

${ }^{*}$ Corresponding Author.

E-Mail : Mergend7@gmail.com

Copyright (C) 2019, Otoritas : Jurnal Ilmu Pemerintahan, ISSN: 2088-3706 (Print), ISSN: 2502-9320 (Online) 


\section{INTRODUCTION}

In the fall of 2010, Bahrain authorities arrested 23 Shiite citizens due to alleged connections to terrorism and attempted coup against the government (Ghannam, 2011). While these men were officially condemned, local human right organizations described government allegations as a crackdown with the goal to strengthen control over the parliamentary elections which followed. Blogger Ali Abdulemam testified in court that he had been tortured, with little chance to consult his lawyer. Internet campaigns soon beganto release Ali, including a wellplanned Twitter attack at Bahrain's Foreign Minister. The Bahrain Online forum established in 1999 by Ali Abdulemam attracted some 100,000 daily mentions with thousands of members, even despite the profound censorship by the government.

Or consider another case. Around 50,000 protesters gathered in downtown Seattle in December 1999 to shut down the processing of the WTO conference (FAIR, 1999). The case is interesting since the way (traditional) mainstream media portrayed the event set the overall tone for public discourse. It also marked the beginning of the global justice cyber movement (Juris 2008; Eltantawy \& Wiest 2011). In US mainstream reports "antitrade" became a common label that described protesters, driven by resentment over the irresponsible dominance of corporations, increased unemployment, and the associated loss of social benefits among vulnerable social strata. The hostility toward peaceful protesters by nearly all major media was especially evident by CBS News, which described protesters as "violent", while CNN referred to them as "a small group of ...anarchists", who "smashed windows and vandalized stores" (In FAIR). It is thus unsurprising that mainstream media justified the use of force. According to Matt Guynn, who was present on the scene and shared his account of police brutality over (online) social media, "I witnessed this morning ... police who had been standing behind a blockade line began marching in lock-step toward the line, swinging their batons forward, and ...began striking the (nonviolent, seated) protestors repeatedly in the back. Then they ripped off the protestors' gas masks, and sprayed pepper spray at point-blank range into their eyes repeatedly". It is needless to mention that the total ignorance of police's way to handle the demonstrations by media is a striking aspect.

The two aforementioned storiesareindeed revealing. The first case highlights the importance of using the internet as a tool for advocacy in an authoritarian political regime. It further suggests that while governments often used to quell opposition's criticism by using traditional means of force, censorship, and finance, today's online tools have created what Mirna Bard (2010) refers to as "the greatest universal shift of our time" (p. 5).The notion of internet is broad, including social media, online communities, search engines (e.g. Google search), blogs, and networking sites such as Facebook, Twitter, Flickr, YouTube, LinkedIn etc. that enable us to connect with others globally in ways deemed impossible before (Brunty et al., 2013; Kaplan and Haenlein, 2010; Fine, 2010). This case is illustrative as it shows that the dissent blogger represented the interests of marginalized groups, while Bahraini political leaders had largely secured the support of the middle class and key business players.

The second story indicates the relevance of the internet in a well-established democracy. It also demonstrates that even a democratic regime is not immune against possible protests when societal frustration is accumulated due to abuse of trust by corporate dominance, diminished social security, and rising unemployment. It is especially revealing for two primary 
reasons. First, the Seattle event took place at the time when the internet was only beginning to rise into prominence. Second, as John Tarleton (2009) mentions, even at a time when the US was "at its zenith" in terms of power and wealth, many young people began to ask themselves how that enormous wealth was being created and to what purpose. The Seattle case is further vital as it led to institutionalization of follow-up organizations such as direct action affinity groups, legal and medical first-aid collectives, newspapers and more.

It is worth noting that while both cases are largely driven by the role of internet, these also reveal high-level frustration among society at large, both in (semi-)authoritarian and democratic regime settings. Such frustration could be particularly driven by widespread corruption among elected officials that eventually led to the emergence of the so-called "Arab Spring" in the Middle East, where corruption is defined here as the abuse of public power for private gain (RoseAckerman \& Truex, 2012, Shah \& Schacter 2004), or "misuse of entrusted power" (Transparency International, 2014). Though being rather broad, these definitions of corruption focus on political and administrative dimensions, such as related to the behavior of elected political leaders and civil servants in a given nation. Protesters in the Arab Spring had kept their dissatisfaction with the government without much eruption well until early 2011, when they finally decided to break out long silence and demanded regime change (Brym et al, 2014). Online tools played a vital role in the process as it transformed both organized groups and informal networks, formed external links, developed a sense of modernity, mobilized resources and drew worldwide attention to the issue (Zhuo et al., 2011). Brym et al, on the other hand, conclude that the net impact of new e-media tools on the 2011 Egypt uprisings was rather minor, as they are low-cost and low-risk means of participation, which may draw numerous passive supporters but who are not quite ready yet to engage themselves in higher-risk activities required by the nature of protests. This suggests that the role of internet in addressing social concerns is subtle, not immediately causal. Hence the internet should be viewed instead as the trigger, which pulled out previously hidden "real" causes onto to the surface when time allowed.

\section{RESEARCH METHODS}

The core method employed throughout this article is a literature review of selected publications on the role of information and communication technologies (ICT) in fighting the evil of corruption, with a major focus on developing nations.

First, it should be noted that the use of literature reviews as a method appears to be quite popular among scholars who study ICT and corruption correlations, both with regard to positive (correlational) outputs (e.g. Bertot et al., 2012) and cases of failure (e.g. Dada, 2006), while others (e.g. Nkohkwo \& Islam, 2013) remain somewhat cautiously optimistic and remind the reader that certain challenges remain, such as digital divide, in the process of ICT implementation especially in the developing world. More broadly, the literature review methodology is often employed in the field of public administration, e.g. on public-private partnerships (Wang et al., 2018), on an experimental approach to studying public administration (Bouwman \& Grimmelikhuijsen, 2016), public service motivation (Ritz, Brewer \& Neumann, 2016) etc.

Second, the need to analyze processes in the context of developing nations is widely reflected across scholarly publications (e.g. Shah 2006; Hickmann et al., 2017). Farazmand (2001) provides possibly the most comprehensive review of comparative public administration cases in developing nations. To summarize, the 
literature review method has been extensively used in the field of public administration, and is the core to this study.

\section{RESULTS AND DISCUSSION}

\section{Political Regimes}

Among a plethora of various modern regimes across the world, this research primarily focuses on two major regimes: democratic and (semi-)authoritarian, due to the rapid proliferation of so-called "hybrid" regimes especially since the end of the Cold War (Levitsky \& Way, 2002). The notion of'hybrid regimes' presents conflicting definitions (Gilbert \& Mohseni, 2011). As Figure 1 shows, there appears to be uniform agreement between scholars on the differences between democracies and non-democracies generally, and yet some disagreement remains between Levitsky and Way's (2002) "competitive authoritarianism" and Schedler's (2002) "electoral authoritarianism", in which governments often revert to various tools such as fraud, repression, as well as the manipulation of actors, cleavages and rules of competition. Nonetheless, the political regime continuum presented below offers sufficient room for classifying selected nations, accordingly. For instance, countries such as the US and Canada can be referred to as liberal democracies, while Kazakhstan falls under the competitive authoritarian regime umbrella. Furthermore, Tufekci \& Wilson (2012) referred to Egypt as modern dictatorship. Political systems across much of Africa, post-communist Eurasian nations such as Russia and Eastern Europe, some Asian nations such as Malaysia and Taiwan, and Latin America have maintained democratic institutions along with elements of authoritarian governance structures since the 1990s (Levitsky \& Way, 2002). Although scholars initially expected that these nations in transition would eventually become democratic, such hopes in many cases proved overoptimistic. Hybrid re- gime, therefore, has become a separate regime in itself. Given the complexity of overlapping definitions, a hybrid regime will be used to embrace semiauthoritarian and semi-democracy regimes.

It is also interesting to analyze the resources mobilized by different regimes in response to or in anticipation of possible conflicts. In her work on the role of online tools in mobilizing protests in Tunisia in January 2011, Anita Breuer (2012) contrasted the resources mobilized by the then existing regime and protesters. President Zine el-Abidine Ben Ali had enjoyed a wide base of support, especially among the middle class. However, there remained two social strata increasingly dissatisfied with the regime - alienated intellectual elites and the rural poor and parts of urban middle class in opposition. The following contextual factors were found to beespecially important: 1 ) online tools allowed a "digital elite" to efficiently build personal networks and thus bypass government censorship; 2) free-riding in collective action was overcome by successfully mobilizing Internet users offline; and 3) it enabled national collective identity to emerge, which facilitated protest activity.

The Ali case inBahrain is very illustrative. The dissent blogger represented the interests of marginalized groups, while Bahraini political leaders had largely secured the support of the middle class and key business players. More interestingly, though, despite the multipleparties involved in the 2011 conflict, there was primarily what Justin Gengler (2012) termed a "single dyad", e.g. Sunni versus Shia religious networks generally, or the standoff between the Sunni-dominated state and the Shia-led opposition. For instance, among the 21 opposition leaders imprisoned in 2012 connected to the protests, only one was Sunni. The resources the pre-protest government tried to mobilize included buying political support of 
citizens through sharing the national fund's oil revenues. However, the rulers have also well understood that many people still remain untouched by the promises made, thus the Bahraini government decided to invest its limited resources toward satisfying the needs of its core constituency, or a minimum winning coalition of supporters (Gengler 2012).

The Seattle case is also very relevant indeed. It well contrasts an informal clash between the traditional mainstream media and what was only beginning to emerge as online media at the time. While traditional print media was quick to describe protesters as "violent", "anarchists", and "vandals", the description offered by online media was dramatically different: it indicated the presence of police brutality, "nonviolent, seated" protestors, and complete obliviousness of traditional media to brutality. The "win" of traditional media in the US case is indeed striking.

To better contrast the resources and strategiesutilized under democratic versus hybrid regimes, it is important to analyze this along the government versus protesters dichotomy in each regime setting. Throughout the Middle East, governments often resorted to blocking and censoring websites, threats, use of force, and torture toward Arab activists, bloggers and journalists (Ghannam, 2011); they also relied on the support of the middle class, as mentioned earlier in the context of Tunisia (Breuer, 2012). The activists, on the other hand, quickly learned ways to efficiently use online tools in hope of removing oppressive regimes. They often used bypass technologies to circumvent attempts to block a website (Al-Saqaf, 2010; Breuer, 2012). The sense of emotional grievance was also employed, whereby protesters focused on the worst aspects of the authoritarian regime (Breuer, 2012). On the other hand, as the Seattle case shows, the federal government relied on traditional media to shape the way protests were broadcast, manipulating mass opinion and yet mobilizing police forces in case the protest turned violent. Seattle activists largely resorted to the use of peaceful, nonviolent demonstrations, campaigns, along with some elements of online tools (in the case of Matt
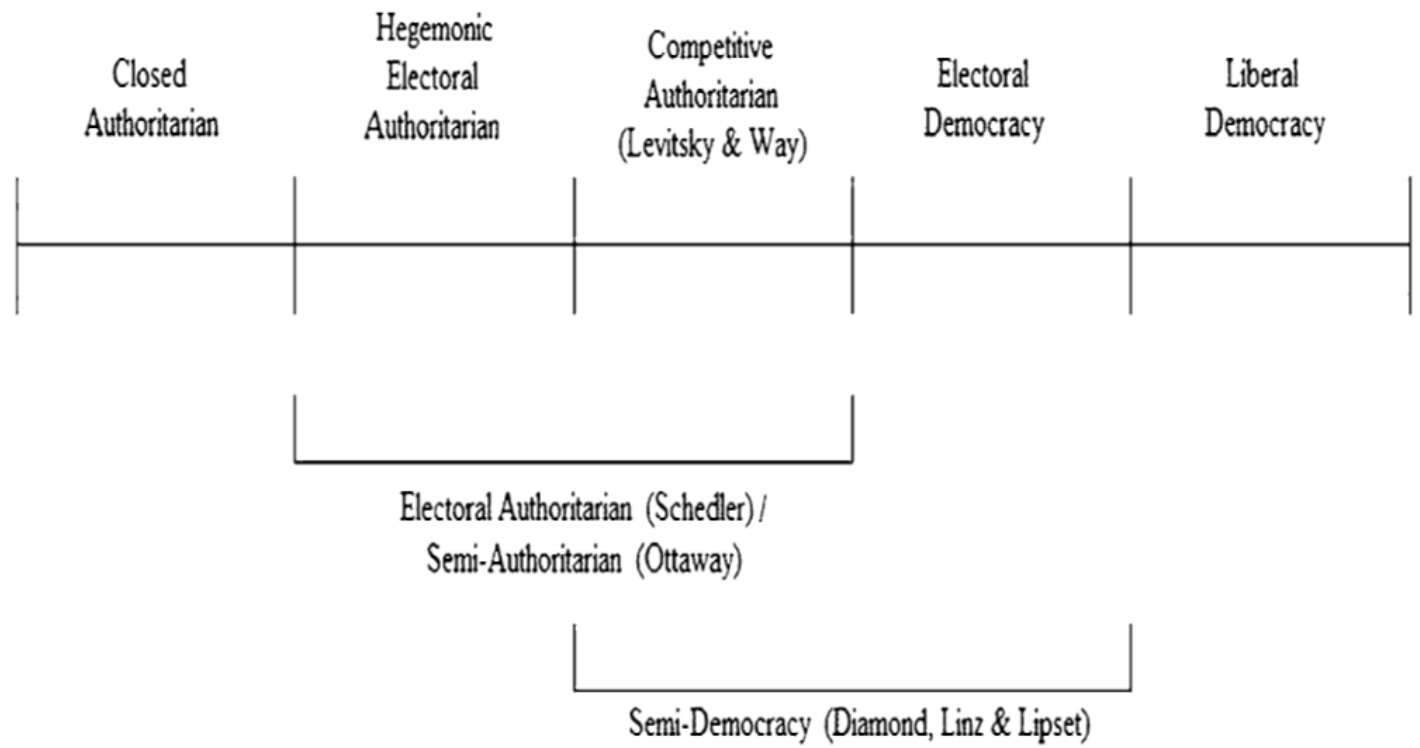

Figure 1. The Political Regime Continuum

Source: Gilbert \& Mohseni (2011) 
Guynn), but not enough to "win" over the then predominant presence of mainstream media (Table 1).

\section{The Notion of Crisis}

To effectively combat corruption and shift a country toward good governance, crisisin governance can be often necessary to instigate further specific action (such as mobilization of mass protests via the use of ICT and social media) aimed at complete eradication of corruption, though this is not sufficient. For instance, in Indonesia, decades-long frustration with widespread corruption led to mass-scale student protests across the country by January 1970, which was viewed as "the strongest anti-corruption outburst" since independence (Quah, 1982). This, however, produced only marginal results, while corruption continues to remain an issue even today. In 1977, the task of fighting corruption was delegated to the National Security Agency (Kopkamtib). As the operation Orderlinessbegan, the NSA conducted a series of "lightning visits" into government offices based on corruption grounds that resulted in a number of arrests. The major impediment of the NSA was its limited capacity to take direct action against highly ranked military officers and top-level officials.

In many instances, crisis still presents a powerful factor that leads to radical transformation in fighting corruption. Hong Kong and Singapore were successful informing strong and efficient anticorruption bodies. In both cases, at certain time a crisis of legitimacy occurred, which set a high sense of urgency for radical anti-corruption reform. RoseAckerman \& Truex (2012) describe this as a "particularly large shock" (p.645). Further, Koh (2010) refers to the crisis moment in Singapore as a matter of "national survival". The majority of western democracies experienced a wave of corruption scandals from the late 1980s to $1990 \mathrm{~s}$, when government efforts to fight this evil were largely limited by the "rising moral tone" of global anticorruption movements (De Sousa, 2009). Furthermore, with regard to the role of ICT and Internet, Lio et al. (2011) conclude that to increase its effect in addressing corruption, other factors should be considered, including a sense of crisis. Finally, Rasambainarivo (2010) observes in the context of Madagascar that it was primarily the "deep political crisis" (p. 256) which necessitated a rapid escalation of the role of ICT and internet tools. Specifically, at the peak of the crisis in 2009, mass protests occurred in Antananarivo, the capital of Madagascar, largely driven by the Internet that allowed its users to instantaneously inform their friends and networks about ongoing events.

\section{ICT as a Factor to Fight Corruption}

Among many factors that affect anticorruption, ICTs are widely viewed as a convenient and cost-effective way to boost transparency and minimize corruption. ICTs can reduce corruption by promoting good governance, monitoring of public employees, and promoting accountability and transparency (Bertot, et al. 2010). Furthermore, ICTs provide access to social media content. While the internet penetration remains low in some countries (Italy, Greece, Mexico, Turkey all with $30 \%$ or less), substantial growth has been observed in mobile technology use, thus supporting the emergence of mobile e-government (Bertot et al. 2010). However, Charoensukmongkol \& Moqbel (2012) observe that while ICT investments can provide infrastructure for effective control of corruption, more investment itself can also present a fertile ground for more corruption. A number of successful ICT projects include, among others, the establishment of anticorruption web-sites called "I paid a bribe" in India and "I made a bribe" in China, where citizens can exchange their 
concerns and experience paying bribes to officials without disclosing their names. On the other hand, government corruption can greatly distort funds spending. One such example is Nigeria, where investments to open ICT resource centers in Edo State were so poorly handled that a government official actually signed off a one million dollar contract to buy a communication dish that was worth around a thousand dollars (Charoensukmongkol \& Moqbel, 2012). As a result, a U-curve relationship is found between ICT investment and reduced corruption: excessive investments can lead to greater corruption (Charoensukmongkol \& Moqbel, 2012). Furthermore, Kim (2013) argues that ICT effectiveness as an anti-corruption tool "depends on educated and civilized human capital and sound technological infrastructure".

\section{Different Perception of the Role of the Internet in Addressing Corruption}

A vast body of literature suggests a positive role of the internet and online tools associated with reducing corruption acrossnations. However, the degree of importance and/or intensity mayvary. The major types of the Internet's role as perceived by various scholars can be broken into the following: instrumental, some- what important, and critical/ very important in addressing corruption issues across different countries (Table 2).

First, a number of scholars believe that the role of internet and online tools is rather instrumental. For instance, as New York Times columnist Thomas Friedman noted as part of his commencement speech at Tulane University in 2011 when referring to Tahrir Square, "What brought Hosni Mubarak down was not Facebook... It was a million people in the streets, ready to die, for what they believed in." (Friedman, 2011). In addition, Biygautane (2015) highlights the role of anticorruption agencies in lowering corruption in the UAE and Qatar, while attributing an instrumental role to both traditional (print) and online media, being the platforms through which law enforcement agencies can quickly display the names and crime descriptions of those found guilty of crime. Finally, Charoensukmongkol \& Moqbel (2012), as mentioned earlier, found a U-curve relationship between ICT and anti-corruption measures, suggesting that investments in ICT can be effective to a certain degree, after which it may lead to reverse effects, especially across certain African countries, such as Nigeria. In other words, the use of ICT is country- and region-specific,

Table 1. Resources and Strategies Utilized by Governments and Activists in Democratic Versus Hybrid Regime Settings

Source: Analyzed by the author (2018)

\section{Hybrid regimes (Middle East)}

\section{Democratic regime (US)}

Blocked websites, censorship, use

Government of force, torture, support of middle class

ICT \& the Internet, use of bypass

Activists software, networks with NGOs,
Use of mainstream (and online) media, manipulating mass opinion, use of police force (as needed)

Peaceful protests, campaigns, and the Internet emotional grievance, aggressive protests and gatherings 
while remaining generally instrumental in reducing corruption.

Second, other scholars assign a somewhat important role to the internet in addressing corruption. According to Sturges (2004), the internet may be a vital tool to lower petty corruption, but in combination with other factors, such as low poverty, better accountability, transparency and political will. Lio et al. (2011) estimate the effects of Internet use on lowering corruption across 70 countries with a time span of 1998-2005, and find the effect to be statistically significant, though not substantial, with possible explanation being the presence of other factors such as bureaucratic reform, democracy, a sense of crisis, political will and leadership. Bhatnagar (2002) analyzed the role of internet and online platforms in reducing corruption using cases studies across South Korea and a number of developing countries, and observed partial success of initiatives. While cases of the OPEN (Online Procedures Enhancement for Civil Applications) system of Seoul Municipality and the Land Record Computerization project in India's state of Karnataka produced higher efficiency, the success of implementing similar projects in Chile and Ecuador showed limited success. This is explained by the lack of strong leadership, political will and presence of resistance toward reform in the latter group. Further, Kim et al. (2009) evaluate the development of the OPEN system in Korea by incorporating three dimensions of institutionalization - regulatory, cognitive and normative. The authors found the regulatory dimension to be most effective, and strong leadership was also crucial. Finally, Pathak et al. (2009) examined the perception of public service delivery in the context of Fiji in light of the potential of internet-enabled platforms to effectively combat corruption and enhance sound governance. Following a survey of community perceptions, a series of interviews with selected officials and relevant literature review, it suggests that service delivery oriented internet initiatives can prove to be efficient in reducing corruption as long as factors such as political will, strong leadership, and institutional support are in place, along with a lack of cultural resistance and fear of technology.

Finally, yet others claim that the internet plays a critical or very important role in reducing corruption across various parts of the world. For instance, Bailard (2009) notes the transformational role of mobile phone penetration across the 46 African countries analyzed, with a corre-

Table 2. Various Types of the Role of the Internet and ICT in Addressing Social Issues Source: Analyzed by the author (2018)

\begin{tabular}{|c|c|c|c|}
\hline $\begin{array}{l}\text { Types of the } \\
\text { role of so- } \\
\text { cial media \& } \\
\text { ICT }\end{array}$ & Instrumental or mixed & Somewhat important & $\begin{array}{l}\text { Critical/ very im- } \\
\text { portant }\end{array}$ \\
\hline $\begin{array}{l}\text { Scholars, as } \\
\text { suggested } \\
\text { by the liter- } \\
\text { ature re- } \\
\text { view }\end{array}$ & $\begin{array}{l}\text { Friedman (2011), } \\
\text { Eltantawy \& Wiest (2011), } \\
\text { Biygautane (2015), Char- } \\
\text { oensukmongkol \& Moqbel } \\
\text { (2012), Brym et al. (2014) }\end{array}$ & $\begin{array}{l}\text { Bertot et al. (2010), } \\
\text { Sturges (2004), Zhuo et } \\
\text { al. (2011), Lio et al. } \\
(2011) \text {, Kim (2013), } \\
\text { Bhatnagar (2002), Kim } \\
\text { et al. (2009), Pathak et } \\
\text { al. (2009), Breuer } \\
(2012)\end{array}$ & $\begin{array}{l}\text { Bailard (2009), } \\
\text { Pathak et al. } \\
\text { (2007), Gronlund } \\
\text { (2010), Tufekci \& } \\
\text { Wilson (2010), } \\
\text { Rasambainarivo } \\
\text { (2010), Hellstrom } \\
(2010)\end{array}$ \\
\hline
\end{tabular}


sponding impact on reducing perceived corruption in terms of CPI scores. The spread of mobile phone communication technologies offers a fertile ground for proliferation of the mobile internet (Bertot et al. 2010). Similarly, Gronlund (2010) concludes that despite data scarcity, internet-enabled ICTs can be effective in reducing corruption, especially along with strong administrative reforms. Further, Pathak et al. (2007) conducted a survey of 400 respondents in Ethiopia regarding the potential of internet platforms to reduce corruption and concluded that if implemented strategically, these are vital not only in eliminating corruption, but also in forming an efficient government-citizen relationship structure in Ethiopia.

Furthermore, certain patterns can be observed across the three role categories. For instance, all scholarswho argue in favor of the critical role of the internet in addressing corruption, largely refer to different countries in Africa: Bailard (2009)'s analysis of 46 African countries, Pathak et al. (2007)'s case study of Ethiopia, Gronlund (2010)'s case of Kenya, Hellstrom (2010)'s analysis of the role of ICT in Eastern Africa, and Rasambainarivo (2010)'s case of Madagascar. The only exception here is Tufekci \& Wilson (2010), who analyze the role of online tools in Egypt. Next, there appear to be less clear patterns across the "somewhat important" column. Bertot et al. (2010) analyze the role of ICT and mobile internet penetration in reducing corruption across democratic and hybrid regimes, e.g. Korea, India, Pakistan, Chile, the US etc. However, three studies within this category employ statistical (regression) analysis as a major method, while only two do so in the "critical" role category, e.g. Bailard (2009) and Tufekci \& Wilson (2010), and one in the "instrumental" role category. Yet it should be noted that since the "somewhat important" category happens to generate the bulk of sources, the relatively higher number of statistical analysis papers does not really appear to be a clear pattern. Finally, in the "instrumental" role category, the majority of scholars referred to the case of Egypt, except Biygautane (2015) who attributes a larger role to law enforcement in reducing corruption across Qatar and the UAE, and Charoensukmongkol \& Moqbel (2012) who analyze three cases across India, China and Nigeria. A clearer pattern though is that all countries analyzed in this column happen to be both developing and can be largely characterized as hybrid regimes, except China.

\section{Key Findings}

The two cases of Ali Abdulemam in Bahrain within the context of an authoritarian political regime and Seattle protests within the context of a democratic regime should primarily suggest that neither regime can be assumed to be perfectly immune against mass-scale protests or social demonstrations fueled by longaccumulated frustration toward corruption. However, the two cases point to certain important differences that characterize their respective political regimes. First, with regard to the nature of protests, the Ali case clearly demonstrates the aggressive and violent nature of social uprisings driven by a long accumulated sense of deep societal disappointment with the earlier repressive regime in the context of Bahrain for its inability to provide basic public services and pervasive corruption. Similar observations can be made about Egypt and Tunisia, which can also be characterized as semiauthoritarian regimes. The Seattle case, on the other hand, reveals a picture that might appear somewhat similar and yet distinctly different. While protests erupted in both cases, the Seattle case witnessed a somewhat peaceful demonstration of (predominantly) young individuals whose intention was to stop the proceeding of the WTO conference, largely driven 
by the feelings of resentment over the unethical attitude of corporations, increased unemployment, and eroded social benefits among the vulnerable. Although these are not the feelings that can be easily dismissed as trivial, they are, nevertheless, not as severe as the deeply rooted feelings of extreme frustration observed in the context of Bahrain and other Middle East nations. Thus, the degree of emotional severity can plausibly explain the difference in the nature of protests. Furthermore, this observation can also be explained from the viewpoint of the notion of crisis. While crisis appears to have accumulated significantly in most Middle East nations, it has not yet gained critical mass in the US, at least as suggested by the Seattle case. Crisis should be viewed as a mandatory but not a sufficient condition: while decades-long frustration in Indonesia eventually escalated into largescale anti-corruption protests in 1970, it produced marginal results.

Similarly, such a subtle variation in the degree of severity can act as a plausible explanation for different intensity levels in using the internet and ICT tools across the both cases. While the Ali case reveals a "win" of the internet over traditional (print) media, the Seattle case demonstrates a different pattern that suggests continuing dominance of traditional mainstream media in shaping public discourse in the US context. Thus, the two cases disprove the immediate impact of the internet on social uprisings throughout the Middle East, but instead, it should be viewed as a trigger that pulled out earlier hidden "real" causes onto the surface. This supports the findings of Brym et al. (2014), who found that the role of online tools in driving the 2011 uprisings in Egypt was rather minor.

Another finding is that, despite certain variations among scholars on the role of the internet in addressing corruption, this paper largely indicates a somewhat important role. While some sources seem to assign either a very important, or merely an instrumental role to the internet as a tool to reduce corruption across various countries, the bulk of literature, e.g. $47 \%$ of all selected works, seems to assign an important role, while only $24 \%$ suggest an instrumental role. Furthermore, $71 \%$ of selected sources suggest that the role of the internet is either somewhat important or critical. Although this is not a comprehensive analysis by any means, it should nonetheless offer a rough indication regarding the relative importance of the internet in corruption discourse. Regarding certain patterns across the three role categories, the critical role of the internet is largely observed in the context of African countries, while the instrumental role is noted in the context of social uprisings in Egypt.

Finally, cross-country studies slightly outnumber single case studies, e.g. 13 versus 11 sources, using both quantitative and qualitative research methods. However, it is an interesting observation that among the cross-country studies only 5 used statistical analysis, while the overwhelming majority, e.g. the remaining 8 sources in that same category and 11 single case studies, were based on case study and/or descriptive research methods.

Finally, regarding the overall application of the role of internet in addressing corruption across various country cases, it appears that overwhelmingly hybrid regimes and developing economies witness a proportionally larger number of cases vis-à-vis democratic regimes and developed countries. This can be explained by a sense of less urgency and necessity to address corruption in democratic regime settings than across most hybrid regime countries. In overall, however, corruption continues to present a vital issue to various policymakers, and the internet appears to be an important tool to address it. 
Available Online at https://journal.unismuh.ac.id/index.php/otoritas

Otoritas : Jurnal Ilmu Pemerintahan, 9 (1), April 2019, 52

\section{CONCLUSION}

Although being important, corruption tends to be secretive and complex (Transparency International, 2014), with many countries being rather reluctant to disclose entirely true information about their domestic corruption issues. As this research demonstrates, ICTs can serve as an efficient tool to address corruption and other social issues especially in the context of hybrid regimes, as it allows users across the globe the flexibility to share their views on ongoing developments both in their respective and other countries. However, as the two cases of Ali Abdulemam in Bahrain and Settle in the United States demonstrate respectively, the role of ICT is relevant in both political regimes. Furthermore, the analysis of existing literature suggests that although the role of ICT and the Internet in curbing corruption across various nations is generally somewhat important, their significance appears to be country- and regionspecific. While the critical role of ICT is observed across many of African nations, its instrumental role is found in the context of Egypt (Brym et al, 2014). It is further interesting to observe the "win" of traditional media narrative versus the internet in the Seattle case (FAIR, 1999).

\section{ACKNOWLEDGEMENT}

The author would like to thank Professor Kenneth Paul Tan and Professor Zeger Van Der Wal at Lee Kuan Yew School of Public Policy (NUS) for their guidance and evaluating the original work as part of the Independent Study Module at LKY School and special thanks for colleagues at Institute of Management, the Academy of Public Administration under the President of Kazakhstan.

\section{REFERENCES}

Al-Saqaf, W. (2010). Internet Censorship Challenged - How Circumvention Technologies Can Effectively Outwit Governments Attempts to Filter Content. Alkasir, a case study. Increasing Transparency \& Fighting Corruption Through ICT, 71.

Bailard, C. (2009). Mobile Phone Diffusion and Corruption in Africa. Political Communication, 26(3),

Bard, M. (2010). The Start of a Great Shift. In: Fine, R., (ed.), The Big Book of Social Media: Case studies, stories, perspectives (pp. 5-7). Yorkshire Publishing

Bertot, C.J., Jaeger, P. T., \& Grimes, J. M. (2012). Promoting Transparency and Accountability Through ICTs, Social Media, and Collaborative Egovernment. Transforming Government: People, Process and Policy, 6(1), 78-91.

Bertot, C.J. Jaeger, P., Grimes, J. (2010). Using ICTs to create a culture of transparency: E-government and social media as openness and anti -corruption tools for societies, University of Maryland.

Bhatnagar, S. (2002). E-Government and Access to Information. Global Corruption 1, 24-32.

Biygautane, M. (2015). Anti-Corruption Strategies in the Gulf Cooperation Council's States: Lessons learned and the path forward. In: Zhang \& Lavena (Eds.), Government AntiCorruption Strategies: A crosscultural perspective (pp.187214). CRC Press

Bouwman, R. B., \& Grimmelikhuijsen, S. G. (2016). Experimental Public Administration from 1992 to 2014: A systematic literature review and ways forward. International 
Available Online at https://journal.unismuh.ac.id/index.php/otoritas

Otoritas : Jurnal Ilmu Pemerintahan, 9 (1), April 2019, 53

Journal of Public Sector Management, 29(2). 110-131.

Breuer, A. (2012, October). The Role of Social Media in Mobilizing Political Protest: Evidence from the Tunisian Revolution. German Development Institute

Brym, R., Godbout, M., Hoffbauer, A., Menard, G. \& Zhang, T. (2014). Social Media in the 2011 Egyptian Uprising. The British Journal of Sociology, 65(2).

Brunty, J., Helenek, K. (2013). Social Media Investigation for Law Enforcement [electronic resource]. Cincinnati, Ohio: Anderson.

Charoensukmongkol, P., \&Moqbel, M. (2014). Does investment in ICT curb or create more corruption? A cross-country analysis. Public Organization Review, 14(1), 5163.

Dada, D. (2006). The failure of Egovernment in developing countries: A literature review. The Electronic Journal of Information Systems in Developing Countries, 26(1), 1-10.

De Sousa, L. (2009, July 7). Anticorruption Agencies: between empowerment and irrelevance. Springer Science + Business Media B.V. http://link.springer.com/ article/10.1007\%2Fs10611-0099211-3

Eltantawy, N. \& Wiest, J. (2011). Social Media in the Egyptian Revolution: Reconsidering Resource Mobilization Theory. International Journal of Communication 5, 12071224

Fairness and Accuracy in Reporting (1999, Dec 7). WTO Coverage: Prattle in Seattle. http://fair.org/ take-action/media-advisories/ wto-coverage-prattle-in-seattle/
Farazmand, A. (2001). Handbook of Comparative and Development Public Administration (2nd, rev. and expand ed.). New York: Marcel Dekker.

Fine, R. (2010). The big book of social media: Case studies, stories, perspectives. Yorkshire Pub.

Friedman, T. (2011). 2011 Speaker Thomas Friedman.Tulane University. Available at: https:// tulane.edu/grads/speakersthomas-friedman.cfm

Gengler, J. (2012, Jan 17). Bahrain's Sunni Awakening. Middle East Research and Information Project. http:// www.merip.org/mero/ mero011712

Ghannam, J. (2011). Social Media in the Arab World: Leading up to the Uprisings of 2011. Center for International Media Assistance

Gilbert, L. \& Mohseni, P. (2011). Beyond Authoritarianism: The Conceptualization of Hybrid Regimes. Springer Science + Business Media, LLC.

Gronlund, A., (2010). Using ICT to Combat Corruption - Tools, Methods and Results, In: Strand,C. (ed.), Increasing Transparency and Fighting Corruption through ICT,7 -31. SPIDER ICT4D Series, 3

Hellstrom, J. (2010). Mobile Technology as a Means to Fight Corruption in East Africa, In: Strand, C. (ed.), Increasing Transparency and Fighting Corruption through ICT, 47-68. SPIDER ICT4D, 3

Hickmann, T., Fuhr, H., Höhne, C., Lederer, M., \& Stehle, F. (2017). Carbon Governance Arrangements and the Nation-State: The reconfiguration of public authority in developing countries. Public Administration and Development, 37(5), 
Available Online at https://journal.unismuh.ac.id/index.php/otoritas

Otoritas : Jurnal Ilmu Pemerintahan, 9 (1), April 2019, 54

331-343. doi:10.1002/pad.1814

Juris, J. (2008). Networking Futures: The Movements Against Corporate Globalization. Durham, NC: Duke University Press

Kaplan, A. and Haenlein, M. (2010). Users of the world, unite! The challenges and opportunities of social media. Business Horizons, 53(1), 5968.

Kim, C. (2013). Anti-Corruption Initiatives and E-Government: A CrossNational Study. Springer Science + Business Media New York.

Kim, S., Kim, H. \& Lee, H. (2009).An Institutional Analysis of an Egovernment System for AntiCorruption: the Case of OPEN. Government Information Quarterly $26,42-50$

Koh, T. H. (2010, October). Corruption Control in Singapore. The 13th International Training Course on the Criminal Justice Response to Corruption. Retrieved from: http://www.unafei.or.jp/english/ pdf/RS_No83/ No83_17VE_Koh1.pdf

Levitsky, S. \& Way, L. (2002).The Rise of Competitive Authoritarianism. National Endowment for Democracy. http:// muse.jhu.edu.libproxy1.nus.edu.s g/journals / journal_of_democracy/ v013/13.2levitsky.html

Lio, M., Liu, M., \&Ou, Y. (2011). Can the Internet Reduce Corruption? A cross-country study based on dynamic panel data models. Government Information Quarterly 28, 47-53.

Nkohkwo, Q. N. A., \& Islam, M. S. (2013). Challenges to the Successful Implementation of e-Government Initiatives in Sub-Saharan Africa:
A Literature Review. Electronic Journal of e-government, 11(1).

Pathak, R., Naz, R., Rahman, M., Smith, R. \&Agarwal, K. (2009). EGovernance to Cut Corruption in Public Service Delivery: A case study of Fiji. Intl Journal of Public Administration, 32: 415-437

Pathak, R., Singh, G. \&Belwal, R. (2007). Governance \& Corruption - Developments and Issues in Ethiopia. Public Organization Review 7(3)

Quah, J. (1982). Bureaucratic Corruption in the ASEAN Countries: A Comparative Analysis of Their AntiCorruption Strategies, Journal of Southeast Asian Studies, Vol. 13, No. 1 (Mar., 1982), 153-177.

Rasambainarivo, H. (2010). Political Crisis as the Lever-Effect to the Expansion of Social. Media: A Case Study of Madagascar, In: Fine, R., (ed.), The Big Book of Social Media: Case Studies, Stories, Perspectives (pp. 255-259). Yorkshire Publishing

Ritz, A., Brewer, G. A., \& Neumann, O. (2016). Public Service Motivation: A systematic literature review and outlook. Public Administration Review, 76(3), 414-426. doi:10.1111/puar.12505

Rose-Ackerman \&Truex, R. (2012, February). Corruption and Policy Reform.Yale Law \& Economics Research Paper No. 444. Retrieved from: http://papers.ssrn.com/ sol3/papers.cfm?

abstract_id=2007152

Schedler, A. (2002). The Nested Game of Democratization by Elections. International Political Science Review, 23 (1): 103-122

Shah, A. (2006). Local governance in developing countries (illustrated.). Washington, DC: World 
Available Online at https://journal.unismuh.ac.id/index.php/otoritas

Otoritas : Jurnal Ilmu Pemerintahan, 9 (1), April 2019, 55

Bank.doi:10.1596/978-0-82136565-6

Shah, A., \& Schacter, M. (2004). Combating corruption: Look before you leap. Finance \& Development, 41 (4), 40-43. http:// search.proquest.com/ docview/209411436? accountid $=13876$

Sturges, P. (2004). Corruption, Transparency and a Role for ICT?. International Journal of Information Ethics, 2(11), 1-9.

Tarleton, J. (2009, Nov 19). Why Seattle Still Matters: 1999 WTO Protests Exposed Deep Flaws in Global Capitalism That Remain Unaddressed.The Indypendent.Retrieved from: https:// indypendent.org/2009/11/19/ why-seattle-still-matters-1999wto-protests-exposed-deep-flaws -global-capitalism-remain- unaddressed

Transparency International (2014). How Do You Define Corruption? Retrieved from: http:// www.transparency.org/ whoweare/organisation/ faqs_on_corruption

Tufekci, Z. \& Wilson, C. (2012). Social Media and the Decision to Participate in Political Protest: Observations from Tahrir square. Journal of Communication, doc. no. 1629

Wang, H., Xiong, W., Wu, G., \& Zhu, D. (2018). Public-Private Partnership in Public Administration Discipline: A literature review. Public Management Review, 20(2), 293316.

Zhuo, X., Wellman, B., \& Yu, J. (2011).Egypt: The First Internet Revolt? Canadian Disarmament Information Service (CANDIS). 